\title{
Structural Features of the Leaf of Ephemeral Species of Representatives of the Brassicaceae Burnett Family in Southwestern Kyzylkum (Uzbekistan)
}

\author{
Gulbakhor S. Tursinbaeva \\ Pedagogical State University Name Nizami, Tashkent, Uzbekistan \\ Email: guljon.duschanova@mail.ru
}

How to cite this paper: Tursinbaeva, G.S. (2019) Structural Features of the Leaf of Ephemeral Species of Representatives of the Brassicaceae Burnett Family in Southwestern Kyzylkum (Uzbekistan). American Journal of Plant Sciences, 10, 1631-1648. https://doi.org/10.4236/ajps.2019.109116

Received: August 19, 2019

Accepted: September 21, 2019

Published: September 24, 2019

Copyright () 2019 by author(s) and Scientific Research Publishing Inc. This work is licensed under the Creative Commons Attribution International License (CC BY 4.0).

http://creativecommons.org/licenses/by/4.0/

(c) (i) Open Access

\begin{abstract}
The results of a study conducted by light microscopy of the anatomical structure of the leaf in ephemeral species from the family Brassicaceae growing under the conditions of Kyzylkum (Uzbekistan) are presented. The following diagnostic, structural adaptive features were revealed: a leaf lamellar, dentate (Diptychocarpus strictus), in Leptaleum filifolium-valky. It is pubescent with various types of trichomes: stellate, dendroid (Meniocus linifolius), equilateral (Streptoloma desertorum) and unequal (Strigosella, Leptaleum filifolium species), unicellular hooked (Leptaleum filifolium). Epidermal cells flattened with wavy or winding walls. The stomata are numerous, not submerged, anomocytic, hemiparacytic, anisocytic types are noted. In all species, the isolate-palisade type of leaf mesophyll predominates. Vascular bundles of all species are sclerified. The main protective features of the leaf of species of the family Brassicaceae are pubescence and sclerification of vascular bundles. We consider the mesomorphic and xeromorphic lines of development ancient and independent. Identified and described signs that can be used in taxonomy and ecology.
\end{abstract}

\section{Keywords}

Anatomy, Leaf, Ephemeral, Brassicaceae, Kyzylkum, Uzbekistan

\section{Introduction}

The Brassicaceae family is very polymorphic, widely distributed mainly in the northern hemisphere (Mediterranean, Western and Central Asia), including 372 genera and more than 4 thousand species. A distinctive feature of the family is 
the abundance of biennial monocarpic (that is, blooming only in the last year of life) herbs [1] [2].

The leaf organs of the ephemera attract the attention of researchers, due to their lability to environmental conditions. The study of their structure in the ontogenesis of plants determines the strategy of adaptation of plants, that is, the path of adaptation during the transition from germinal leaf organs (cotyledons) to the leaf. There is evidence of the leaf structure of several species from different habitats ephemers: Karakum [3], the foothills of Western Tien-Shan [4] [5] and Kopetdag [6]. The type of leaf mesophyll of some types of ephemers of Kyzylkum and the ratio of palisade and spongy tissues are reflected in the works of G.F. Begbaeva [7] [8] [9] [10], G.S. Tursinbaeva and A.A. Butnik [11].

In the capital summary C.R. Metcalfe and L. Chalk [12] noted that leaf trichomes of the species of the family Brassicaceae are very diverse; mesophyll is predominantly dorsiventral, but it is also isolated-palisade. The stomata are anisocytic on both sides of the leaf. Idioblasts with myosin are present in all organs, which, when coagulated, turns red or purple, which can be used as a diagnostic sign. E.I. Volkova [6] studied the structure of 10 species of ephemers, including Brassicaceae species, in the conditions of Kopetdag and the Moscow Region. She noted a variety of leaf types and an increase in mesomorphic under conditions of introduction in the Moscow region. N. Rao and I. Inamdar [13] described the morphology and leaf venation of 35 species of Brassicaceae, including species of the genus Alyssum: leaves are simple, regular, but the shape of the plate is very diverse. Venation is mainly kraspedromny. G.F. Begbaeva [7] described the type of leaf mesophyll in 2 species of Isatis. Isatis species are valuable in nutritional plants, and contain all the essential amino acids and a significant amount of carbohydrates [14]. Thus, information on the leaf structure of desert species of Brassicaceae is scarce.

\section{Materials and Methods}

The objects of research are 13 species of ephemeral representatives of Brassicaceae Burnett family, growing in southwestern Kyzylkum: Diptychocarpus strictus Trautv., Goldbachia laevigata DC., Hymenolobus procumbens Nutt., Isatis minima Bunge., Isatis viollascens Bunge., Lachnoloma lehmanii Bunge., Leptaleum filifolium DC., Meniocus linifolius (Willd.) DC., Strigosella africana (L.) Botsch., Strigosella grandiflora (Bunge) Botsch., Strigosella scorpioides (Bunge) Botsch., Streptoloma desertorum Bunge., Tauscheria lasiocarpa Fisch (Figure 1). Species identified by U.P. Pratov.

The material was collected in the flowering phase in spring-March-April in the Kyzylkum desert station, which is located $160 \mathrm{~km}$ northwest of Bukhara at $40^{\circ} 45^{\prime}$ north latitude and $63^{\circ} 45^{\prime}$ east longitude at an altitude of $375 \mathrm{~m}$ above sea level based sources Ayak-Guzhumdy. The depth of groundwater is $20-30$ $\mathrm{m}$, the mineralization of water is $0.65-1.95 \mathrm{~g} / \mathrm{l}$, in places $4-5 \mathrm{~g} / \mathrm{l}$. Saline chloride-sulfate. The soil is mixed with gypsum $(10 \%-50 \%)$. The soils are diverse: 


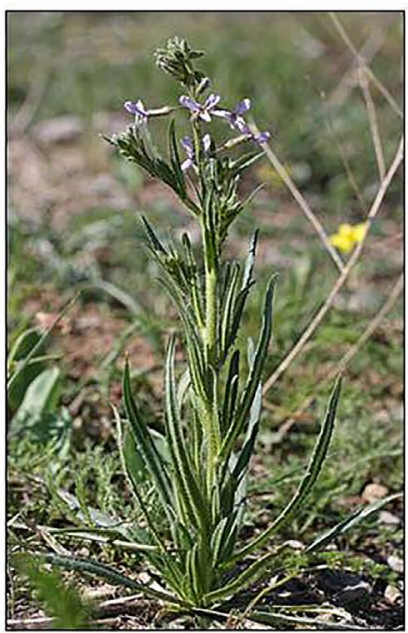

Diptychocarpus strictus

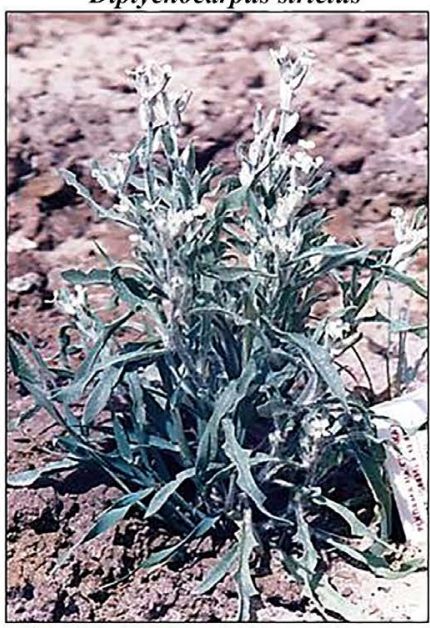

Lachnoloma lechmannii

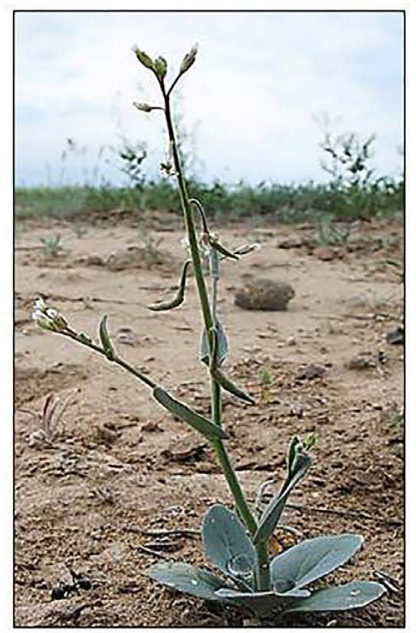

Goldbachia laevigata

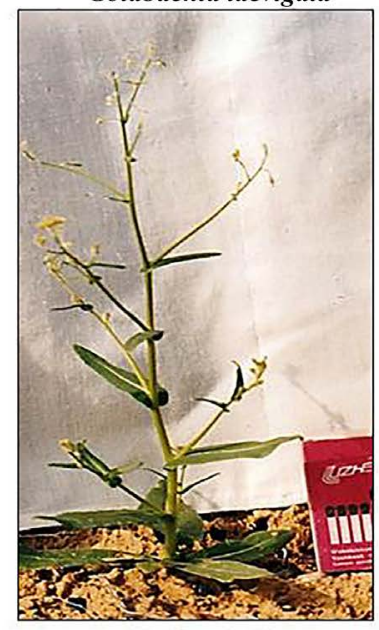

Isatis minima

Figure 1. Species of the family Brassicaceae.

gray-brown gypsum, salt marshes, takyrs, semi-fixed sands, sandy loam, variegated flowers, rocky slopes of the Outlier Mountains, which determines the diversity of vegetation, including ephemera. The region is characterized by extreme dryness of air and soil caused by minimal rainfall ( $80-120 \mathrm{~mm}$ per year), high summer and low winter temperatures from $\max +40^{\circ} \mathrm{C}-45^{\circ} \mathrm{C}$ to $\min$ $-25^{\circ} \mathrm{C}-30^{\circ} \mathrm{C}$ accompanied by a strong wind [15] [16] [17] [18].

Leaves of ephemeral species from the family Brassicaceae were collected in 3 5 pieces. From the lower, middle and upper tiers of shoots of the first and second orders in natural habitats in the budding phase-the beginning of flowering. The type of mesophyll was determined in cross sections through the middle of the leaf. The epidermis was studied on paradermal preparations and cross sections. Sections were made with a dangerous razor, stained with methylene blue, glued to glycerin-gelatin. The shape and shape of the main epidermal cells are described by the method of S.F. Zakharevich [19]. The measurements were carried out according to the standard technique [20]. The preparations were drawn using the RA-6 drawing apparatus under the MBI-3 microscope. The measure- 
ments were carried out in thirtyfold replicates, calculated in average value, measurement errors and significance by B.A. Dospekhov's formula [21] using a personal computer (MS-Excel program).

\section{Results and Discussion}

Diptychocarpus strictus Trautv. The leaf is simple, oblong-linear, sharp-toothed and pubescent with simple and capitated glandular hairs on a 4-cell leg. The epidermis is single-row. From the surface, the cells are spread out, on the adaxial side of the cell wall are wavy, on the abaxial side-sinuous. The stomata are numerous, especially on the abaxial side, anomocytic, hemiparacytic, anisocytic, not submerged. Mesophyll dorsiventral, with 3 rows of broad palisade cells on the adaxial side of the palisade-like, loose on the abaxial. Spongy cells form 5 - 6 rows. Vascular bundles (main and 20 - 22 laterals) are sclerified (Figure 2).

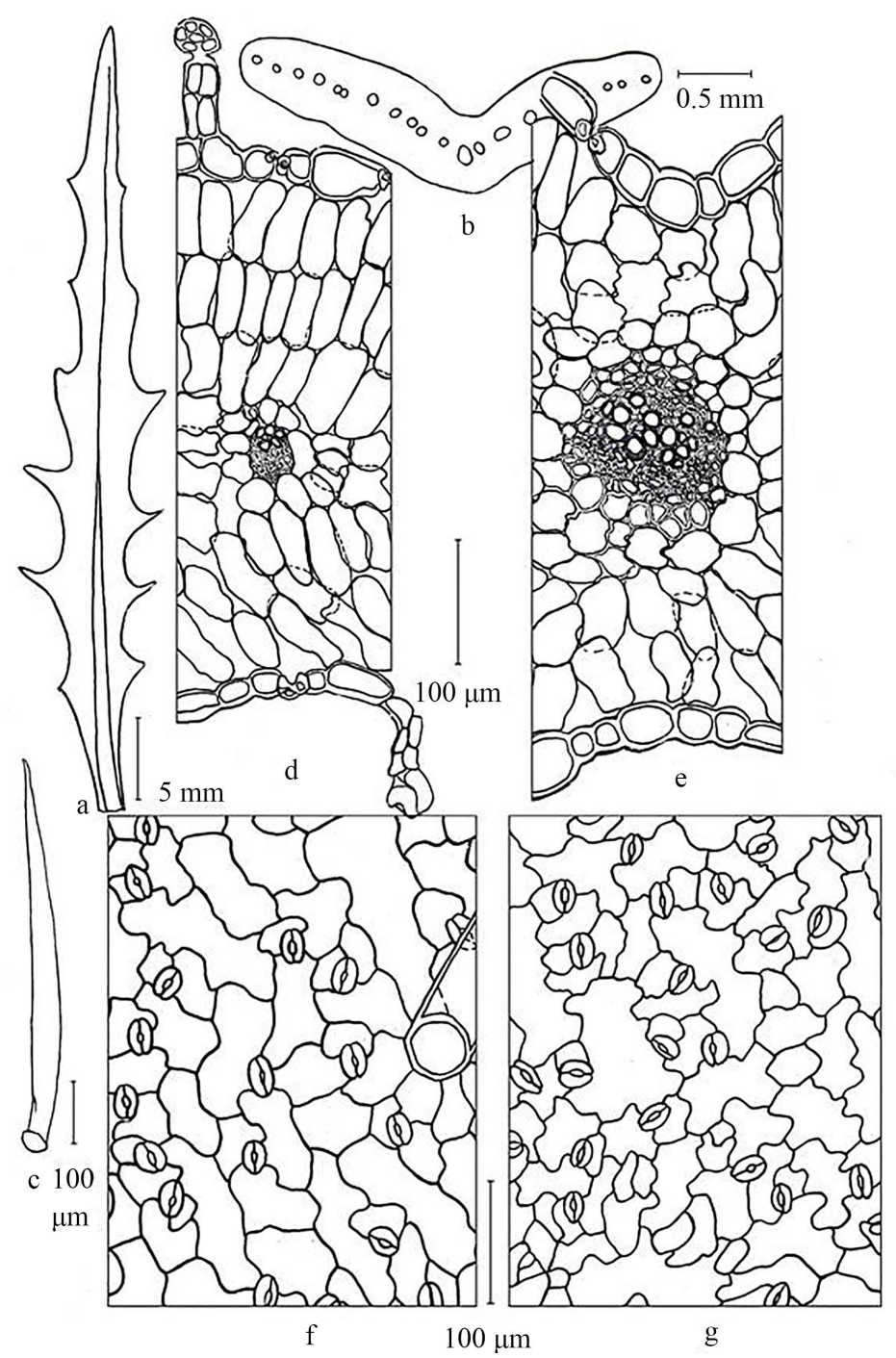

Figure 2. The structure of the leaf Diptychocarpus strictus. a-appearance; b-cross-sectional diagram; $\mathrm{c}$ - trichome; $\mathrm{d}$-detail of mesophyll; $\mathrm{e}-$ main vein; $\mathrm{f}$-adaxial epidermis; g-abaxial. Magnification-0.5 - $5 \mathrm{~mm}, 100$ micron. 
Goldbachia laevigata DC. The leaf is lamellar, at the base is heart-shaped petiolate, rarely serrated at the edges, $8-10 \mathrm{~mm}$ long, $1.5-2 \mathrm{~mm}$ wide. At the top, tapering. It is covered with simple unicellular hairs on a 2-cell base (Figure 3 ). Epidermal cells on the paradermal section are flattened, slightly wavy; in the transverse section they are swollen with a thickened outer wall. The leaf is amphystomatic. The stomata are small, numerous, anomocytic and hemiparacitic, not submerged. Mesophyll is isolated-palisade, on both sides 2 - (3) rows of palisade cells, in the center of $6-7$ rows of spongy cells. The median vascular bundle is larger than the lateral ones, surrounded by a sclerenchymal lining (Figure 3).

Hymenolobus procumbens Nutt. Leaves with homoblastic heterophyllus. The basal leaves are alternate in the amount of $3-5$, up to $1.5 \mathrm{~cm}$ in length, 0.8 $\mathrm{cm}$ in width, lyre-pinnately-pinnately separate with 5 - 8 lobes. Lower stem-1.5 $-1.8 \mathrm{~cm}$ long, $0.5 \mathrm{~cm}$ wide, dissected, with $4-5$ lobes. Medium-1.2 $-1.5 \mathrm{~cm}$

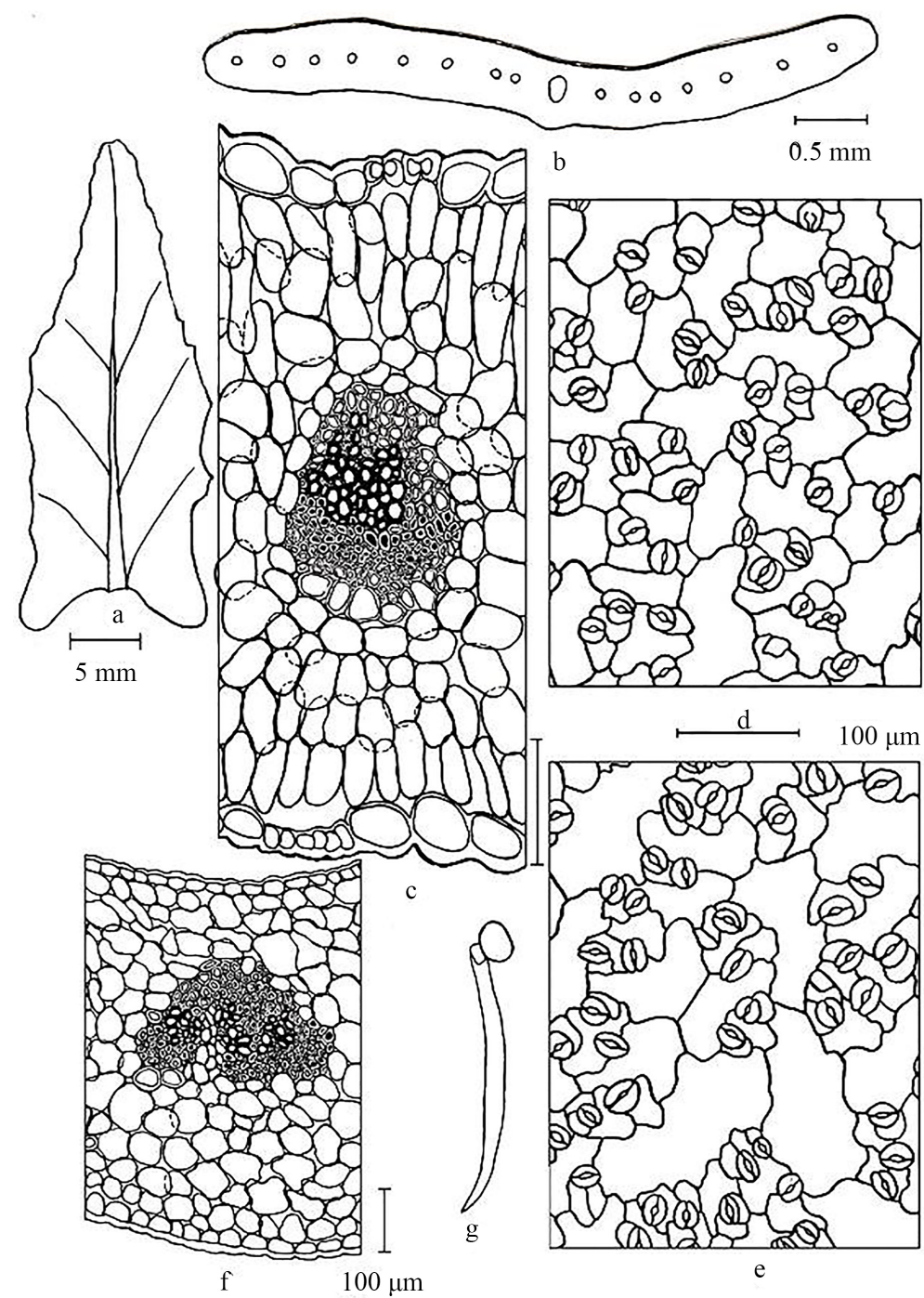

Figure 3. The structure of the leaf Goldbachia laevigata: a-appearance; b-cross-sectional diagram; c-a detail of a mesophyll; d-adaxial epidermis; e-abaxial; $\mathrm{f}-$ main vein; g-trichomes. Magnification-0.5 - $5 \mathrm{~mm}, 100$ micron. 
long, $0.4-0.5 \mathrm{~cm}$ wide, less dissected, oblong, with an elongated slightly pointed apex and an elongated base, short or sessile. Upper leaves $0.5-1 \mathrm{~cm}$ long, $0.1-$ $0.3 \mathrm{~cm}$ wide, whole, sessile. On the paradermal section, the epidermal cells are oblong, their walls meandering on both sides of the leaf. The stomata are anisocytic and hemiparacitic, less often anomocytic, not submerged and randomly oriented (Figure 4). On the cross section of the leaf of the middle tier of the epidermis, single-row, and its outer walls are thickened $(4.7 \mu \mathrm{m})$. Mesophyll is isolated-palisade, 277.9 microns thick. On the adaxial side there are 3 rows of palisade cells, on the abaxial side there are 2 rows with large intercellular spaces and 6 rows of spongy cells between them. The palisade ratio is $45 \%$, the cell palisade index is 2 . The median vascular bundles with 10 - 15 vessels, small lateral bundles-10 - 12. All beams are sclerified due to thickening of the walls of the phloem parenchyma (Figure 4).
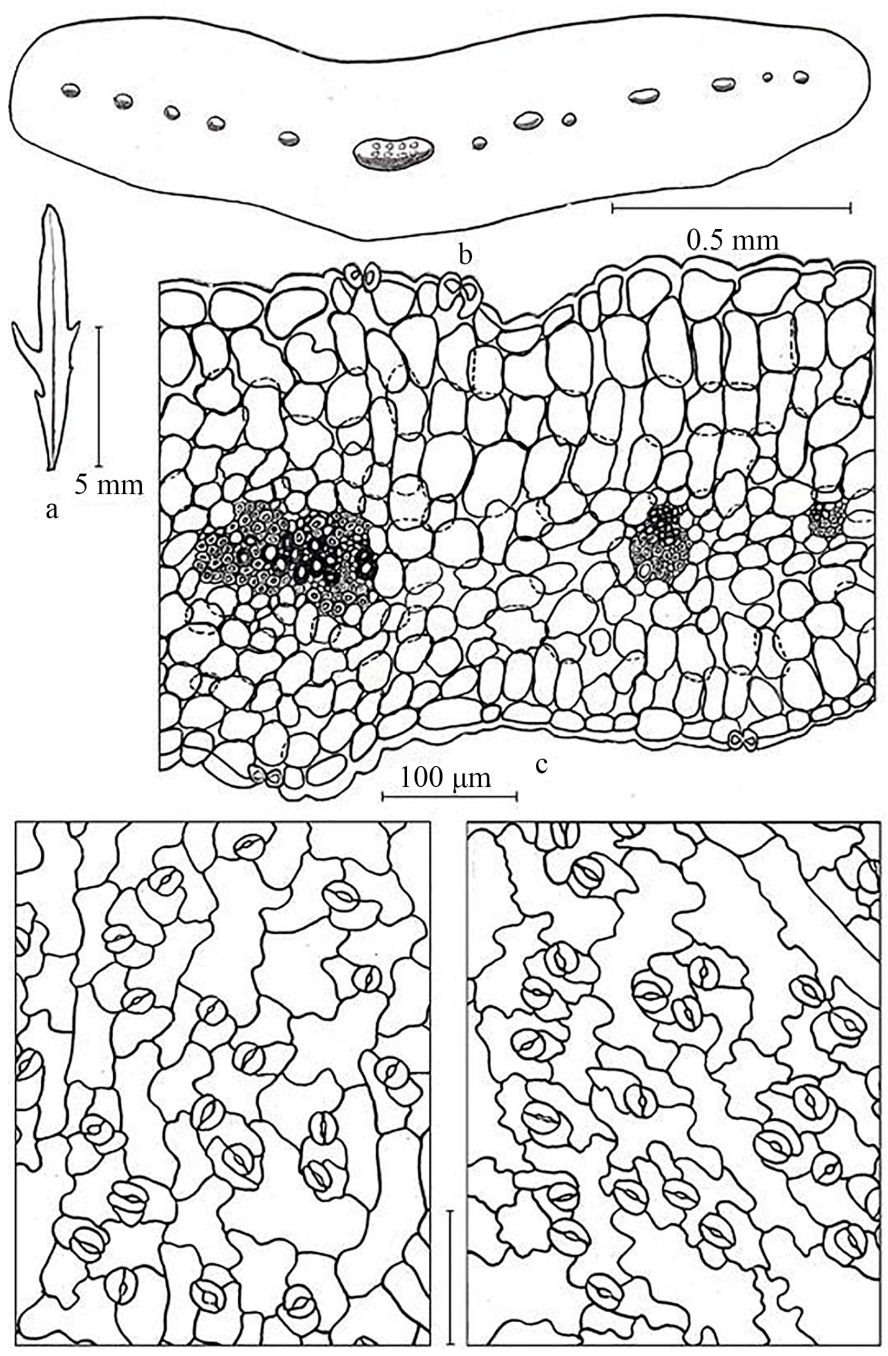

d

$100 \mu \mathrm{m}$

e

Figure 4. The structure of the middle leaf of Hymenolobus procumbens: a-appearance; $\mathrm{b}-$ cross-sectional diagram; $\mathrm{c}-\mathrm{a}$ detail of a mesophyll; $\mathrm{d}$-adaxial epidermis; e-abaxial. Magnification-0.5 - $5 \mathrm{~mm}, 100$ micron. 
In ontogenesis in $H$. procumbens the adaptation of assimilating organs changes towards an increase in the degree of helio- and xeromorphism, expressed in the transition from the dorsiventral cotyledon mesophyll to the isolate-palisade leaves. However, the structure of the autonomic organs also carries mesomorphic features: the tortuosity of epidermal cells, large intercellular spaces in the leaf mesophyll and not submerged small numerous stomata.

Isatis minima Bunge. The leaf is simple, finely serrated, with an outstanding vein on the abaxial side. The epidermis is single-row. The epidermal cells are spread out, their walls are wavy, higher on the adaxial side, sinuous and large on the abaxial. The leaf is amphystomatic. The stomata are numerous, small, anomocytic, rarely hemiparacitic and anisocytic, unloaded. Mesophyll is isolated-palisade, with 2- (3) rows of palisade cells on the adaxial side and 1 on the abaxial. The spongy tissue is 6 - 7-row, loose, with large intercellular spaces. The median conductive bundle extends from the adaxial and even more from the abaxial side. Lateral vascular bundles on a cross Section 10. All beams are sclerified (Figure 5).

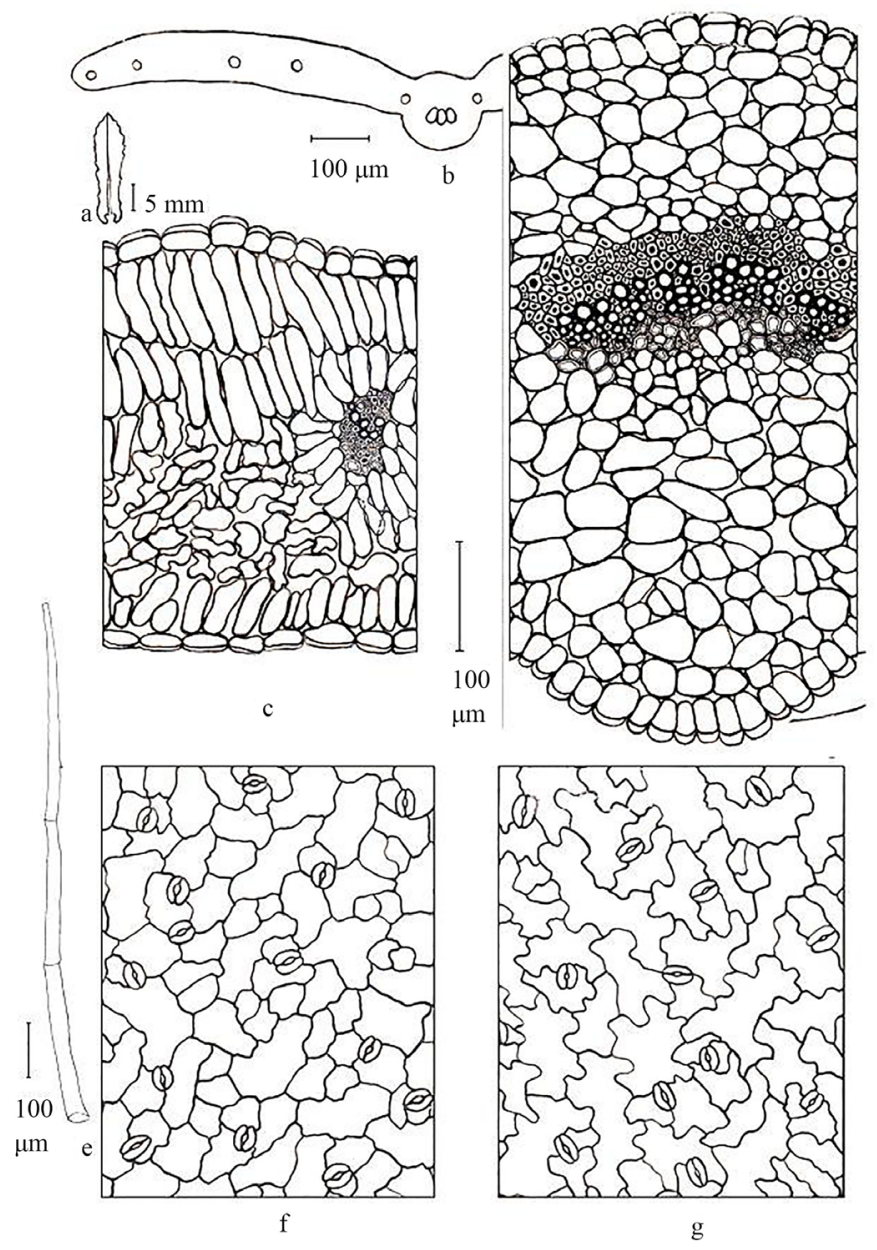

Figure 5. The structure of the middle leaf Isatis minima: a-the appearance of the sheet; $\mathrm{b}$-cross-sectional diagram; $\mathrm{c}$-a detail of a mesophyll; $\mathrm{d}$-main vein; $\mathrm{e}$-trichome; $\mathrm{f}$-adaxial epidermis; g-abaxial. Magnification-0.5 - $5 \mathrm{~mm}, 100$ micron. 
Isatis viollascens Bunge. The leaf of the middle tier of the shoot is flat, expanded at the base and narrowed to the apex, with an outstanding middle vein, pubescent with thin filiform and thick short hook-shaped trichomes (Figure 6). The epidermal cells of a flattened form with curving and wavy walls, on the abaxial side, contain anthocyanin's that protect against insolation. The leaf is amphystomatic. The stomata are numerous, large and small, anomocytic, hemiparacytic, anisocytic, not submerged (Figure 6). Mesophyll dorsiventral, friable. Palisade parenchyma 2-row, spongy 7 - 8-row with large intercellular spaces. The median beam is strongly sclerified from all sides. Lateral vascular bundles 24 - 26 on the cross section, small, but also sclerified. At the base of the leaf, the entire mesophyll tissue is parenchyma, the main vein is large, sclerified (Figure 6).

Lachnoloma lehmanii Bunge. The leaf of the middle tier is lamellar, coarse toothed on a wide petiole, pubescent with branched hairs. The epidermis is single-row, adaxial 16.3 microns high, abaxial-19.7 microns, flattened, slightly wavy from the surface (Figure 7).

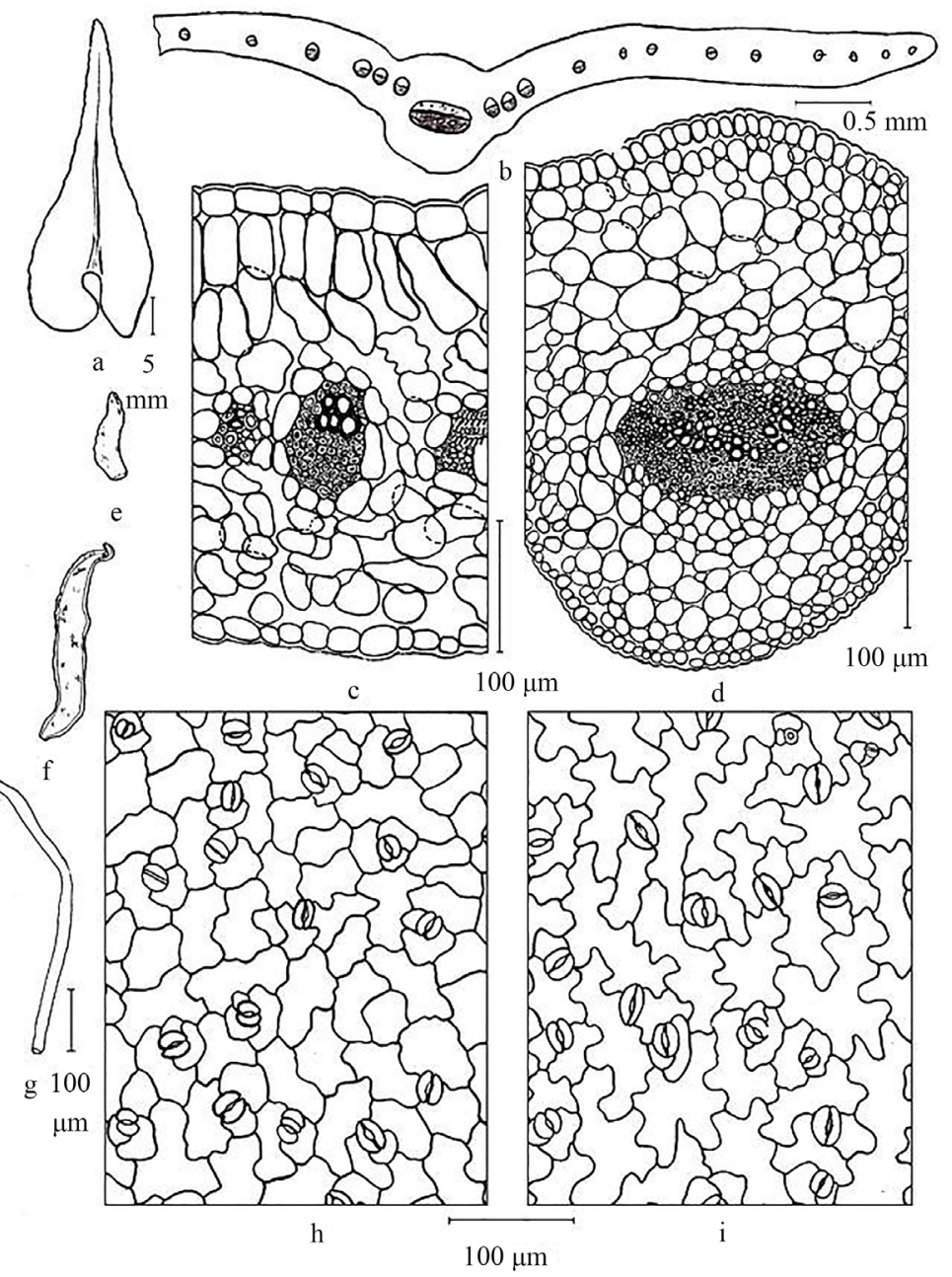

Figure 6. The structure of the middle leaf of Isatis viollascens: a-appearance; b-crosssectional diagram; c-a detail of a mesophyll; d-main vein; e, f, g-trichomes; $\mathrm{h}$-adaxial epidermis; i-abaxial. Magnification-0.5 - $5 \mathrm{~mm}, 100$ micron. 


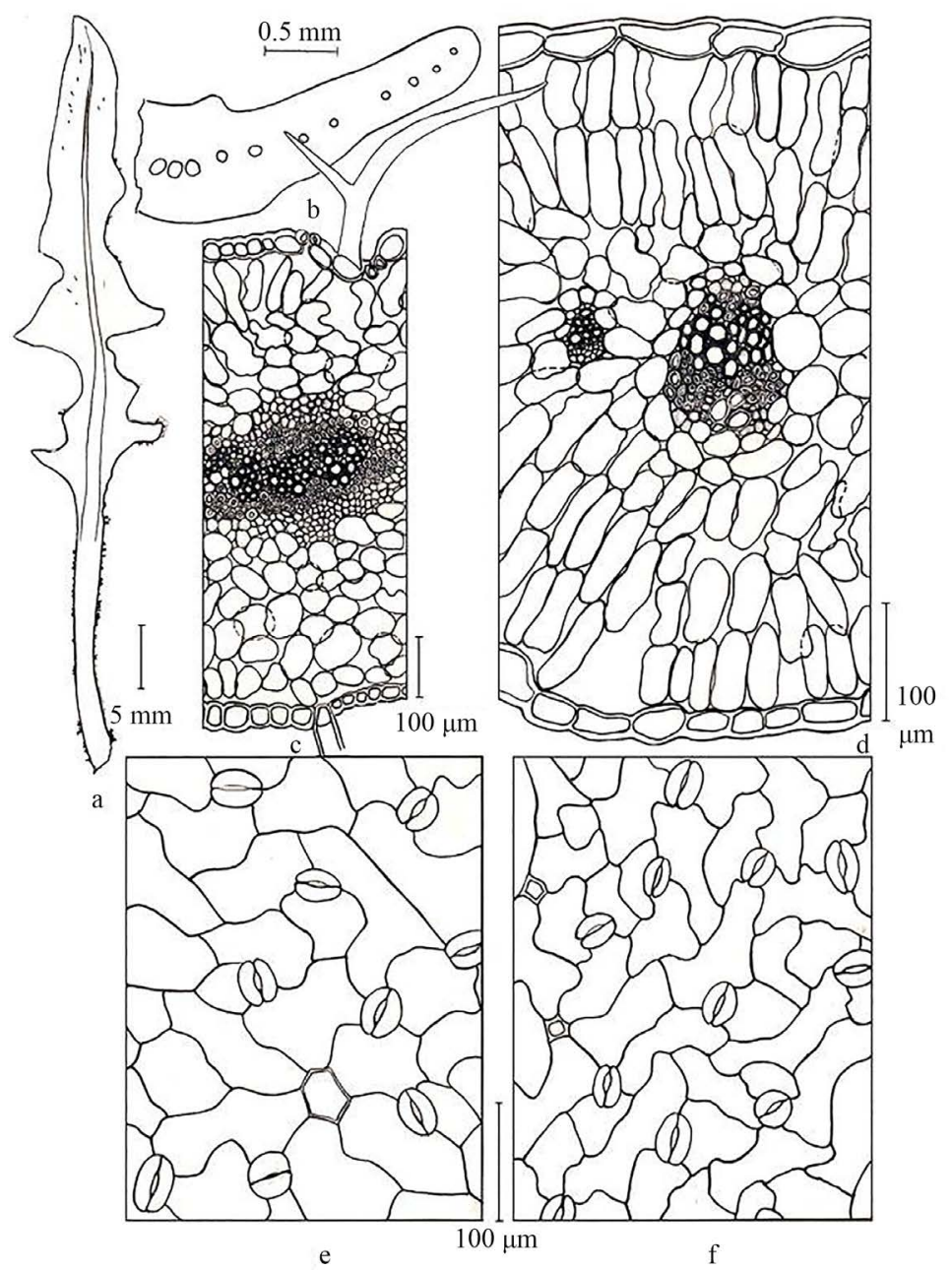

Figure 7. The structure of the middle leaf of Lachnoloma lehmanii: a-appearance; $\mathrm{b}-$ cross-sectional diagram; $\mathrm{c}$ - $\mathrm{a}$ detail of a mesophyll; $\mathrm{d}-$ main vein; $\mathrm{e}$-adaxial epidermis; f-abaxial. Magnification-0.5 - $5 \mathrm{~mm}, 100$ micron.

Adaxial cells are larger than abaxial, with an outer wall thickness of $4.3-4.4$ microns. The leaf is amphystomatic. The stomata are not submerged, mainly anomocytic, oval, 31.8 (adaxial) and 32.9 (abaxial) microns long, 26.5 and 27.7 microns wide, respectively. Mesophyll is isolated-palisade, with 2 rows of palisade cells on the adaxial side and 2 - 3 on the abaxial. The height of the palisade cells is 64.5 and 57.3 microns. Spongy parenchyma $4-5$ rows. Mesophyll loose with large intercellular spaces. The median bundle is larger than the lateral ones (16 on the transverse section), surrounded on all sides by the sclerenchyma, lateral bundles slightly sclerified (Figure 7).

Leptaleum filifolium DC. A leaf $3-3.5 \mathrm{~cm}$ long, divided into 5 - 6 narrow ( 1 - $1.5 \mathrm{~mm}$ wide) lobes, pubescent with 1 - 2 radial hairs with curved hook-shaped ends of the rays. On the adaxial side above the vein, a recess is noticeable, with the abaxial side, a protrusion. The epidermis is single-row. On the adaxial side, the cell walls are slightly wavy, on the abaxial side, meandering, the outer walls of the cells thickened. The leaf is amphystomatic. The stomata are small, nu- 
merous, anomocytic, less often hemiparacitic, not submerged. There are no stomata on the adaxial side above and below the main vein. In cross section, the proportion of a crescent-shaped leaf with blunts ends. Mesophyll is isolateral-palisade with 3 rows of palisade cells on both sides of the plate, between them 4 - 5 rows of spongy cells. The intercellular spaces are large. On the cross section of the leaf lobe, 4 large vascular bundles and $5-6$ small ones pass. The main and large lateral vascular bundles with $15-20$ vessels are surrounded by a sclerenchymal lining. The leaf is xeromorphic due to the reduction of the evaporating surface (narrow lobes), the thickened outer walls of the epidermis, the isolate-palisade mesophyll ( 3 rows of cells on each side) and the sclerification of the vascular bundles (Figure 8).

Meniocus linifolius (Willd.) DC. The leaf is linear, solid, $3-3.5 \mathrm{~cm}$ long, and 3 - $4 \mathrm{~mm}$ wide, pubescent with stellate hairs. The epidermis is single-row, from the surface of flattened cells with slightly wavy, often straight walls. The stomata are small, numerous, not submerged, anomocytic, hemiparacitic and paracytic, arranged randomly. Mesophyll is isolated-palisade (Figure 9).

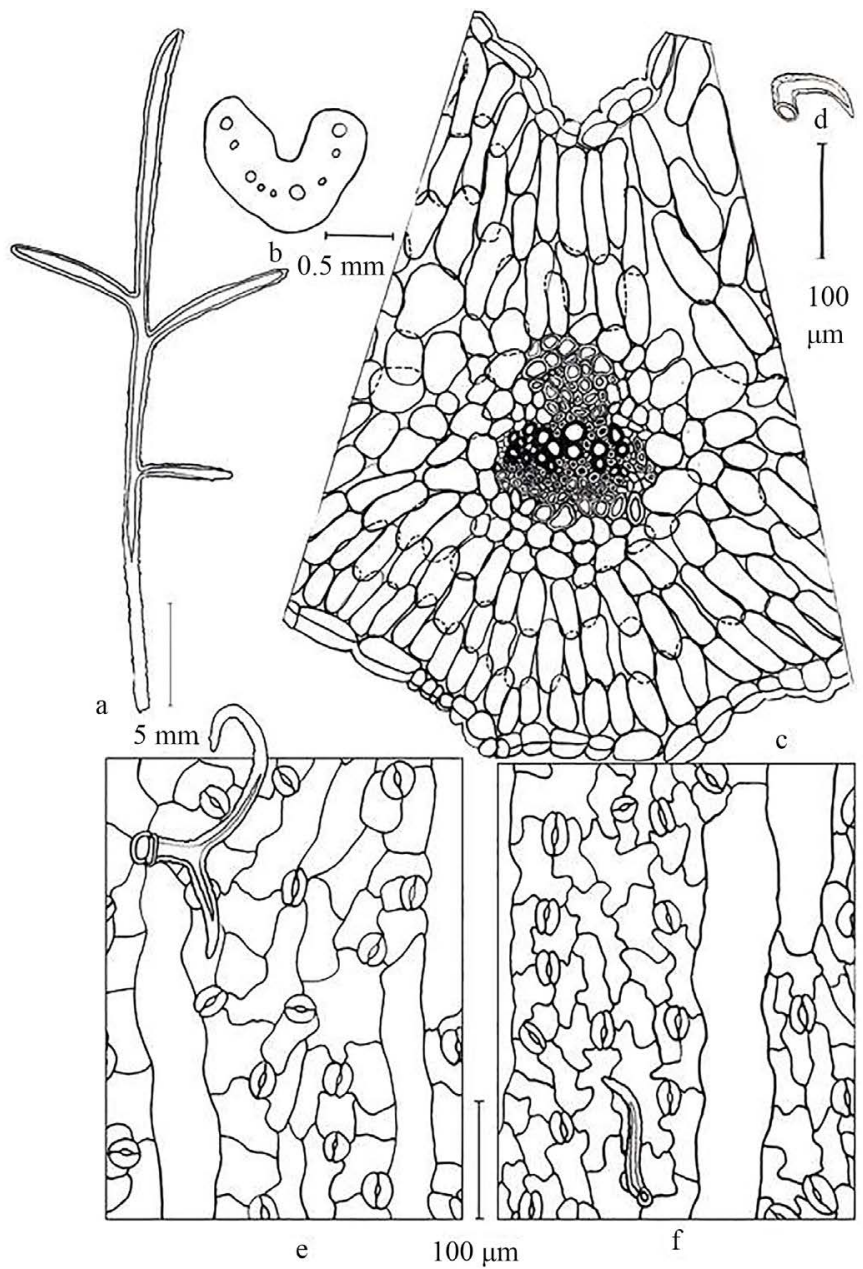

Figure 8. The structure of the middle leaf of Leptaleum filifolium: a-appearance; bcross-sectional diagram; $\mathrm{c}$-a detail of a mesophyll; $\mathrm{d}$-hook-shaped trichome; $\mathrm{e}$-adaxial epidermis; f-abaxial. Magnification-0.5 - 5 mm, 100 micron. 

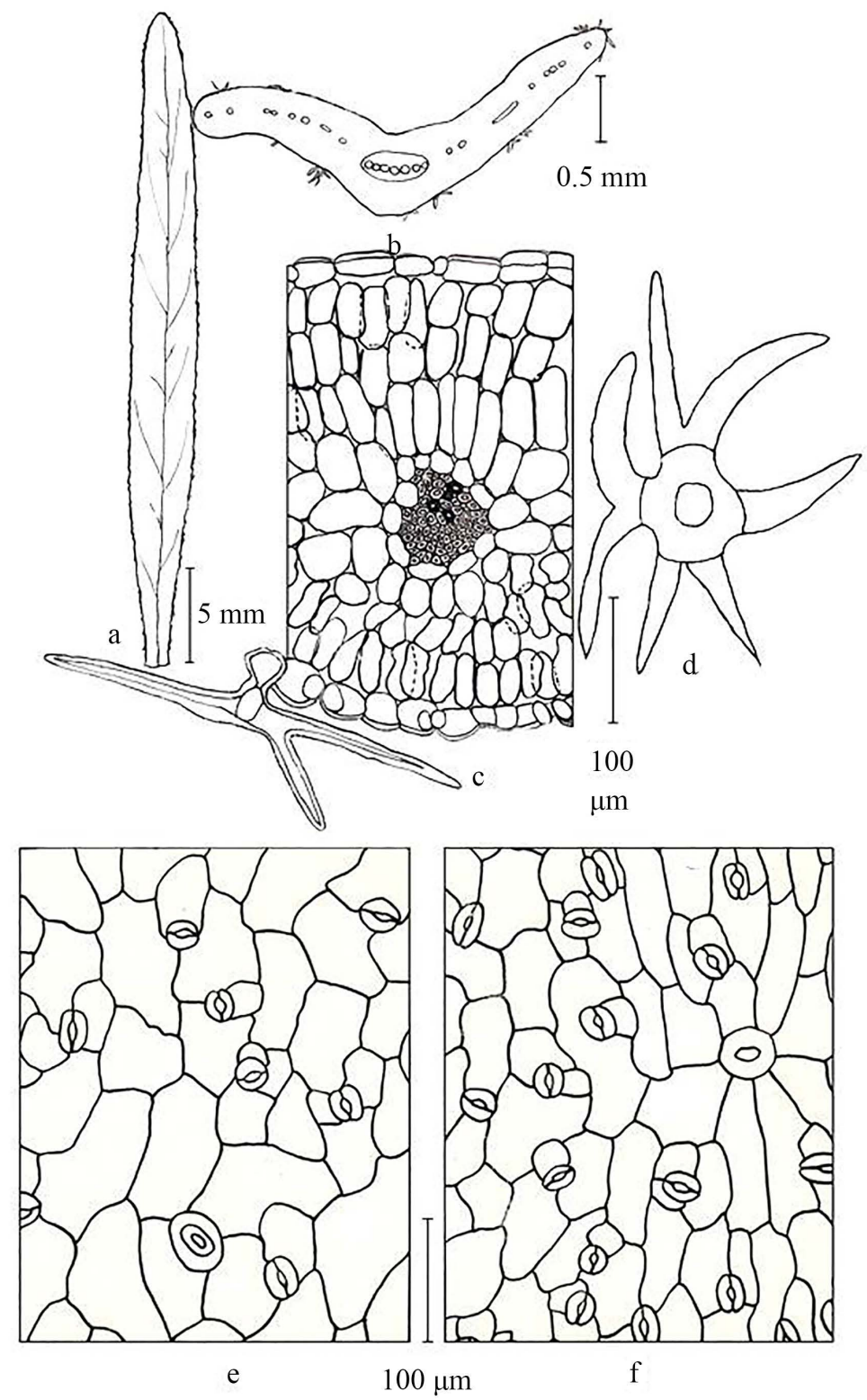

Figure 9. The structure of the middle leaf Meniocus linifolius: $\mathrm{a}$-appearance; $\mathrm{b}$-crosssectional diagram; c-a detail of a mesophyll; d-trichome; e-adaxial epidermis; $\mathrm{f}$-abaxial. Magnification-0.5 - $5 \mathrm{~mm}, 100$ micron.

On the adaxial side, it is represented by 3 rows of palisade cells, from the abaxial $1-2$. Between them 4 - 5 rows of spongy cells. The intercellular spaces are small. The median bundle is large, with numerous vessels, highly sclerified, surrounded by a parenchymal lining. The lateral bundles (15 - 16 in the transverse section) are also sclerified; the vessels in them are few. The leaf is xeromorphic due to pubescence from stellate trichomes, small intercellular spaces, sclerification of vascular bundles (Figure 9).

Strigosella africana (L.) Botsch. The leaf is large, $33-35 \mathrm{~mm}$ long, $10-12$ wide, oblong-oval, serrated at the edges, on a wide petiole, pubescent with single and double-ray hairs with small spines. The main vein extends from the under- 
side of the leaf. The epidermis is single-row, from the surface of the cell are flattened, on the adaxial side of the wall are slightly wavy, on the abaxial, sinuous. The stomata are numerous not submerged, anomocytic, rarely hemiparacitic and anisocytic, arranged randomly. Mesophyll dorsiventral, loose, 2 - 3 rows of large wide palisade cells located on the adaxial side and $6-8$ rows of spongy cells with abaxial. The median vein is large, with numerous vessels, sclerified from all sides. The lateral veins are also sclerified and surrounded by a parenchymal lining (Figure 10).

Strigosella grandiflora (Bunge) Botsch. The lower rosette leaves are oblong, petiole, finely serrate, pubescent along the edge with simple bulbous and cellular hairs. The epidermis is single-row. On the surface of the cell, the adaxial epidermis is 4 - 5-faced with straight walls, and the abaxial cells are flattened with wavy

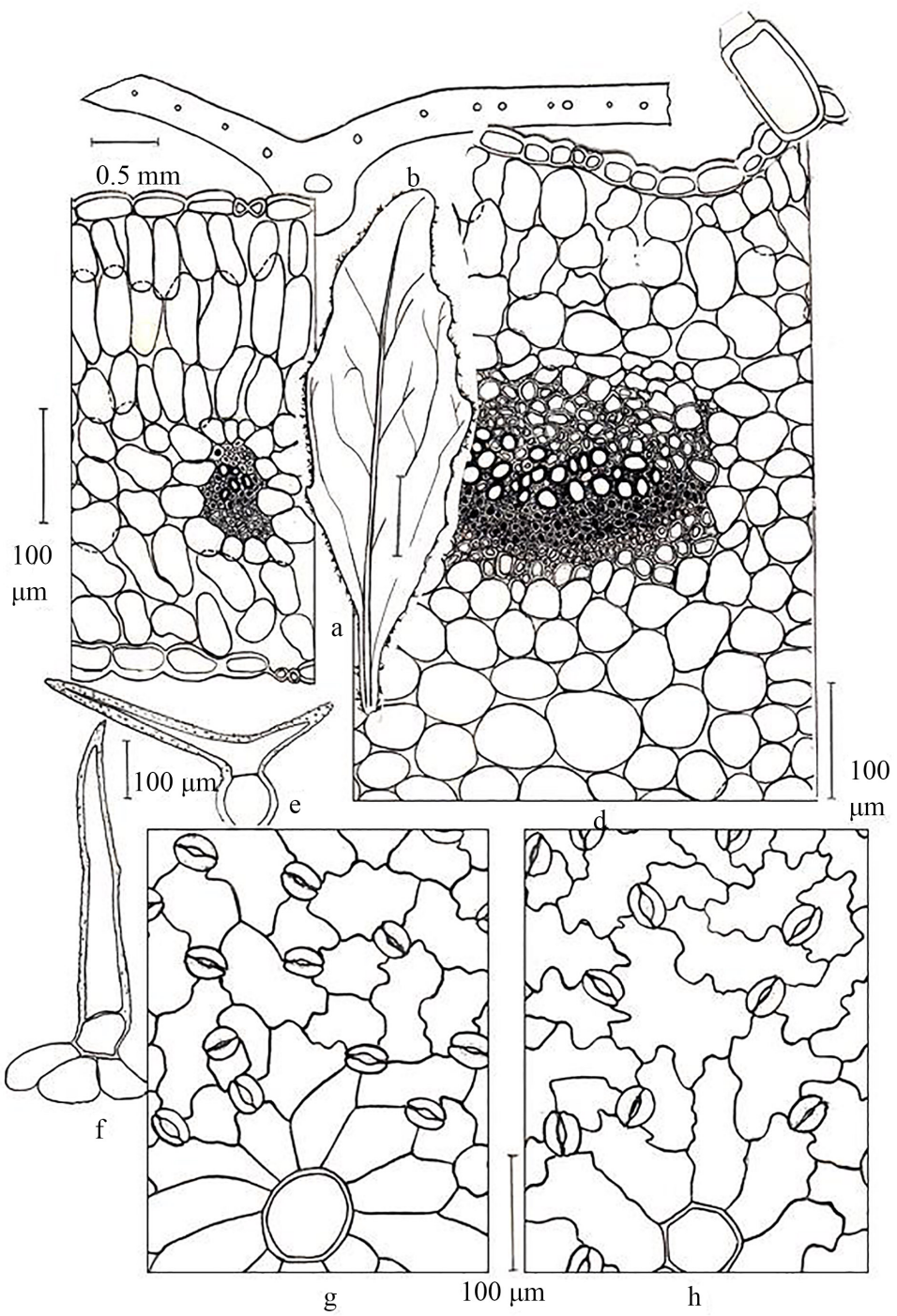

Figure 10. The structure of the leaf of the middle tier of Strigosella africana: a-appearance; $b$-cross-sectional diagram; $c-a$ detail of a mesophyll; $d-$ main vein; $\mathrm{e}-$ multibeam trichome; $\mathrm{f}$-glandular trichome; g-adaxial epidermis; $\mathrm{h}$-abaxial. Magnification- 0.5 - $5 \mathrm{~mm}, 100$ micron. 
walls. The stomata are small, numerous, anomocytic, hemiparacitic, anisocytic, arranged randomly, not submerged. The outer wall of the cells is greatly thickened. Mesophyll dorsiventral: on the adaxial side 2 rows of palisade cells, spongy parenchyma 5 - 6-row, friable with large intercellular spaces. In the region of the median vein, palisade cells are absent. The vein is issued on the abaxial side, consists of 2 - 4 closely connected sclerified beams. The lateral vascular bundles are small, on the transverse section $-15-17$, with several vessels, sclerated (Figure 11).

Strigosella scorpioides (Bunge) Botsch. The leaf is elongate-lobate, wholemarginal, sometimes finely serrated, oval-elongated, and pubescent with unicellular branched and double-beam hairs, with an expanded petiole. The epidermis is single-row, from the surface the shape of the cells is flattened, on the adaxial

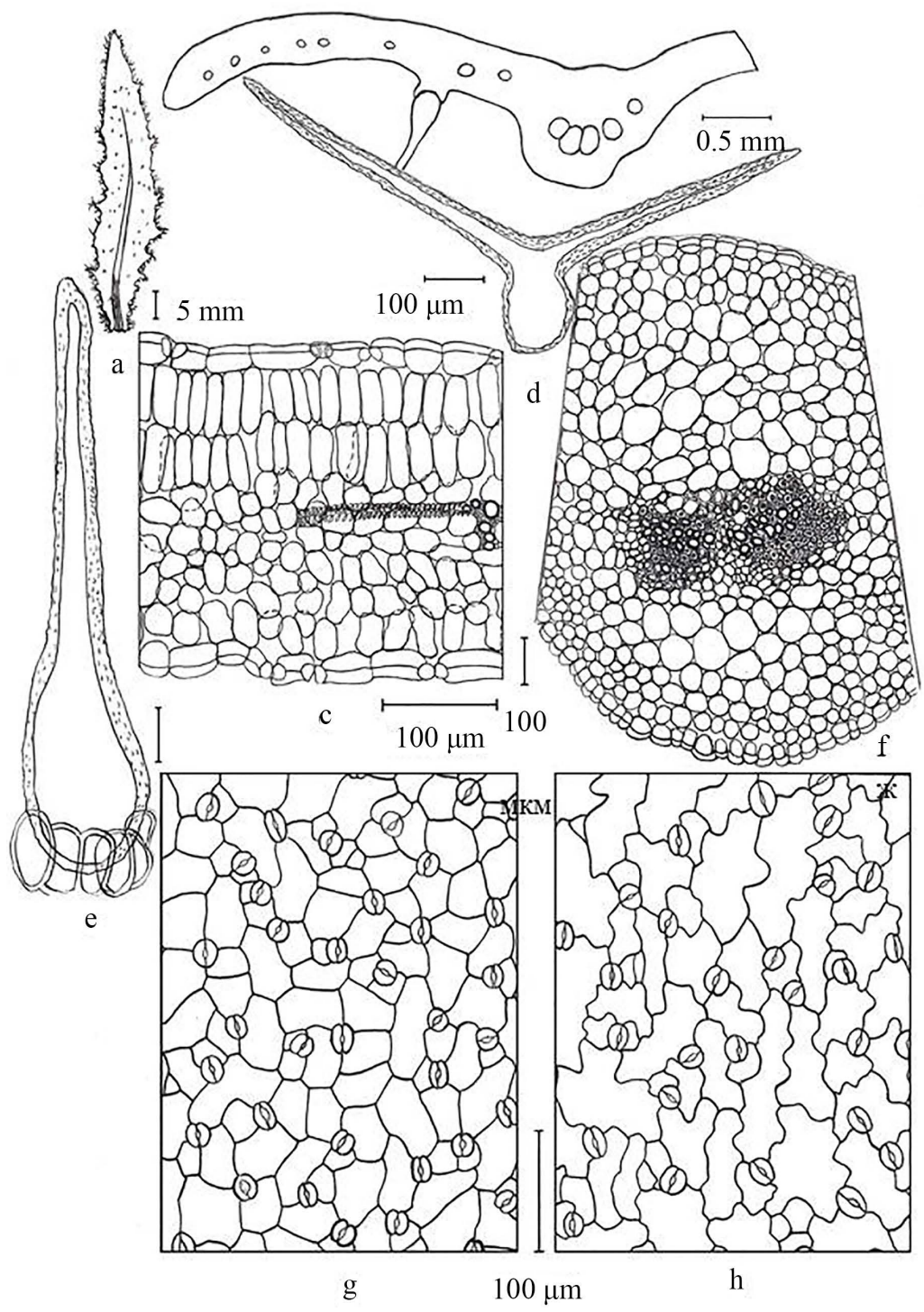

Figure 11. The structure of the leaf Strigosella grandiflora: a-appearance; b-cross-sectional diagram; c-f-detail of a mesophyll; d-multibeam trichome; e-glandular bulbous trichome; f-adaxial epidermis; g-abaxial. Magnification-0.5 - $5 \mathrm{~mm}, 100$ micron. 
side of the cell wall is wavy, on the abaxial side-sinuous. The stomata are numerous, anomocytic, rarely hemiparacytic and anisocytic, not submerged, randomly located. Mesophyll leaf dorsiventral. Palisade parenchyma from the adaxial side 2-row, spongy parenchyma 5 - 7 rows. The intercellular spaces are small. The median vein is issued from the abaxial side, sclerified from all sides. The lateral veins in the cross section are $16-18$, they are small, with $1-3$ vessels, sclerified (Figure 12).

Streptoloma desertorum Bunge. The leaf of the middle tier is lyre-shaped, coarse and fine-toothed, with a plate of $0.5-1.0 \mathrm{~cm}$ in length and $10 \mathrm{~mm}$ in width of the teeth, on a flattened petiole. It is pubescent with simple and branched trichomes with spines. The epidermal cells are large, spread out, with slightly wavy walls. The stomata are oval, anomocytic and rarely hemiparacitic, not submerged. The outer wall of epidermal cells is slightly thickened. Mesophyll is isolateral-palisade with 3 rows of palisade cells on the adaxial side and 2 palisade-like on the abaxial side. Between them are 3 - 4 rows of loose spongy cells,

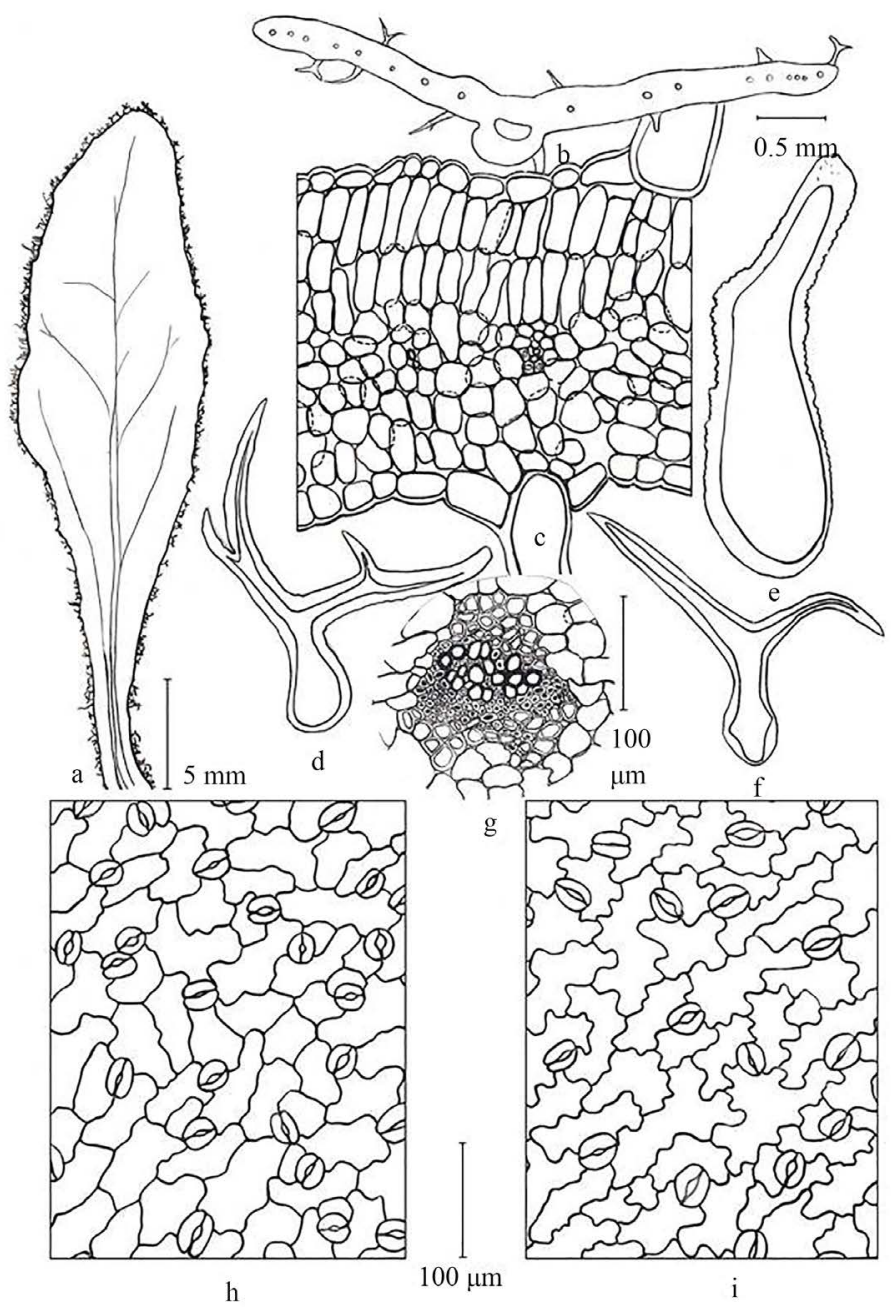

Figure 12. The structure of the middle leaf of Strigosella scorpioides: a-appearance; $\mathrm{b}-$ cross-sectional diagram; $\mathrm{c}-\mathrm{a}$ detail of a mesophyll; $\mathrm{d}, \mathrm{e}, \mathrm{f}-$-multibeam trichomes; g-main vein; h-adaxial epidermis; i-abaxial. Magnification-0.5 - $5 \mathrm{~mm}, 100$ micron. 
the intercellular spaces are large. The main vein smoothly protrudes from the abaxial side, consists of 3 closely aligned sclerified vascular bundles. The lateral bundles on the transverse section (16 - 18) are small-not clerical, large-sclerified (Figure 13). The upper leaf is whole-edge with an expanded apex and narrowed base, pubescent with 1 - 2-cell trichomes. Its structure is more xeromorphic. The stomata are numerous, especially on the abaxial side. The leaf blade is thinner, the mesophyll is denser. On the adaxial side, 3 rows of palisade cells with a palisade index of 3.0 - 3.5 are clearly expressed, on the abaxial side, 1.5 2.0. In the median vein there are 3 - 5 sclerified conducting beams, lateral ones-8, that is, heterophyllium and heteromorphic of the structure are clearly expressed (Figure 13).

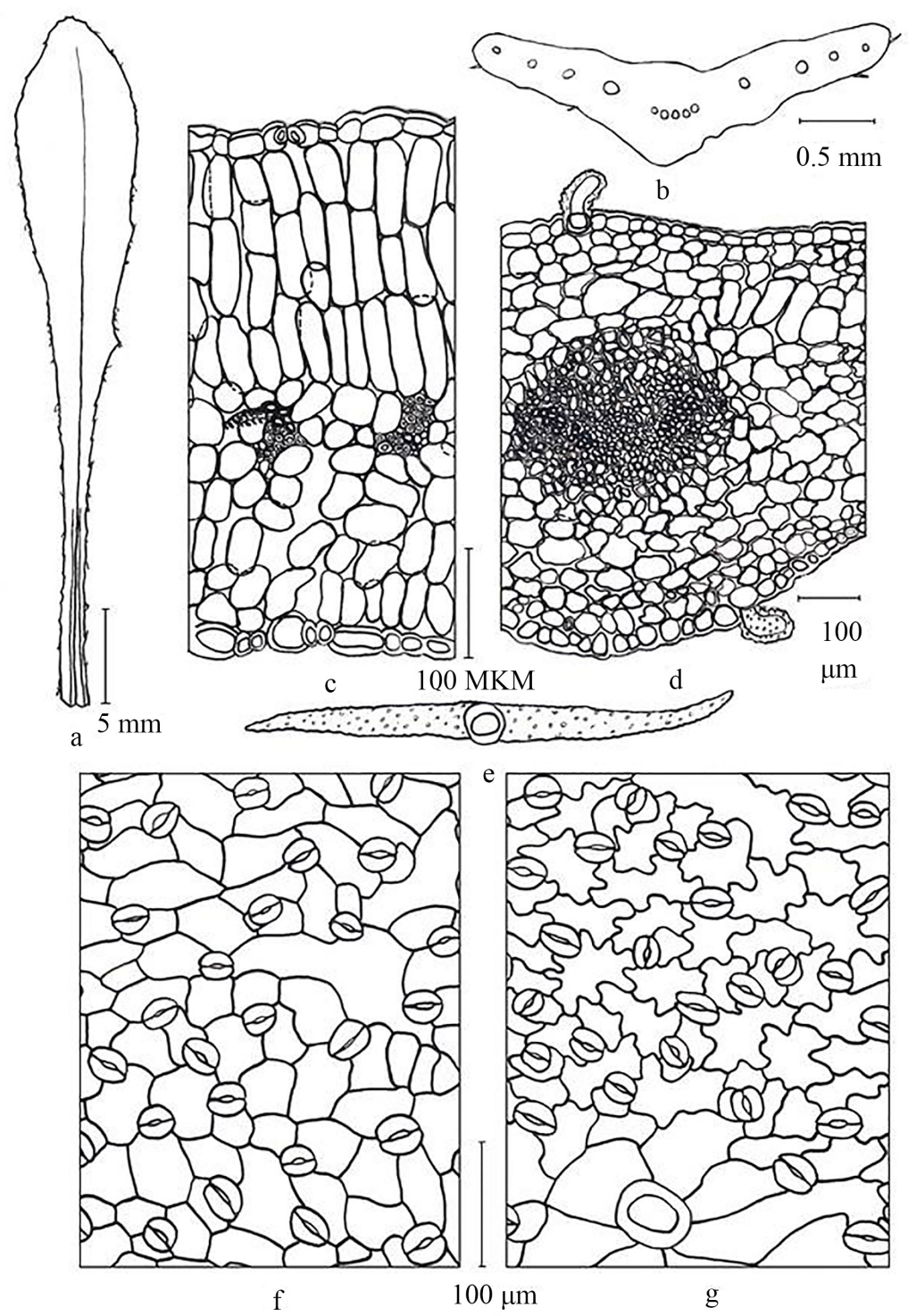

Figure 13. The structure of the middle leaf Streptoloma desertorum: a-appearance; $\mathrm{b}$-cross-sectional diagram; $\mathrm{c}$ - $\mathrm{a}$ detail of a mesophyll; $\mathrm{d}$-main vein; e-double-beam trichome; f-adaxial epidermis; g-abaxial. Magnification-0.5 - 5 mm, 100 micron. 
Tauscheria lasiocarpa Fisch. The middle leaf is lamellar with a heart-shaped base, sessile, with an outstanding main vein. The epidermis is single-row, from the surface of the cell are flattened, their walls are winding, on a cross section with a thickened outer wall. The leaf is amphystomatic. The stomata are numerous, small anomocytic and hemiparacytic, not submerged. Mesophyll is isolated-palisade. On the adaxial side, 2 rows of large palisade cells, on the abaxial side, 1 row. Between them 4 - 5 rows of loose spongy parenchyma (Figure 14).

The intercellular spaces are large throughout mesophyll. The median bundle is sclerified from the abaxial side, the vessels are few (Figure 14).

Thus, the leaf of the species of the Brassicaceae family is lamellar, dentate
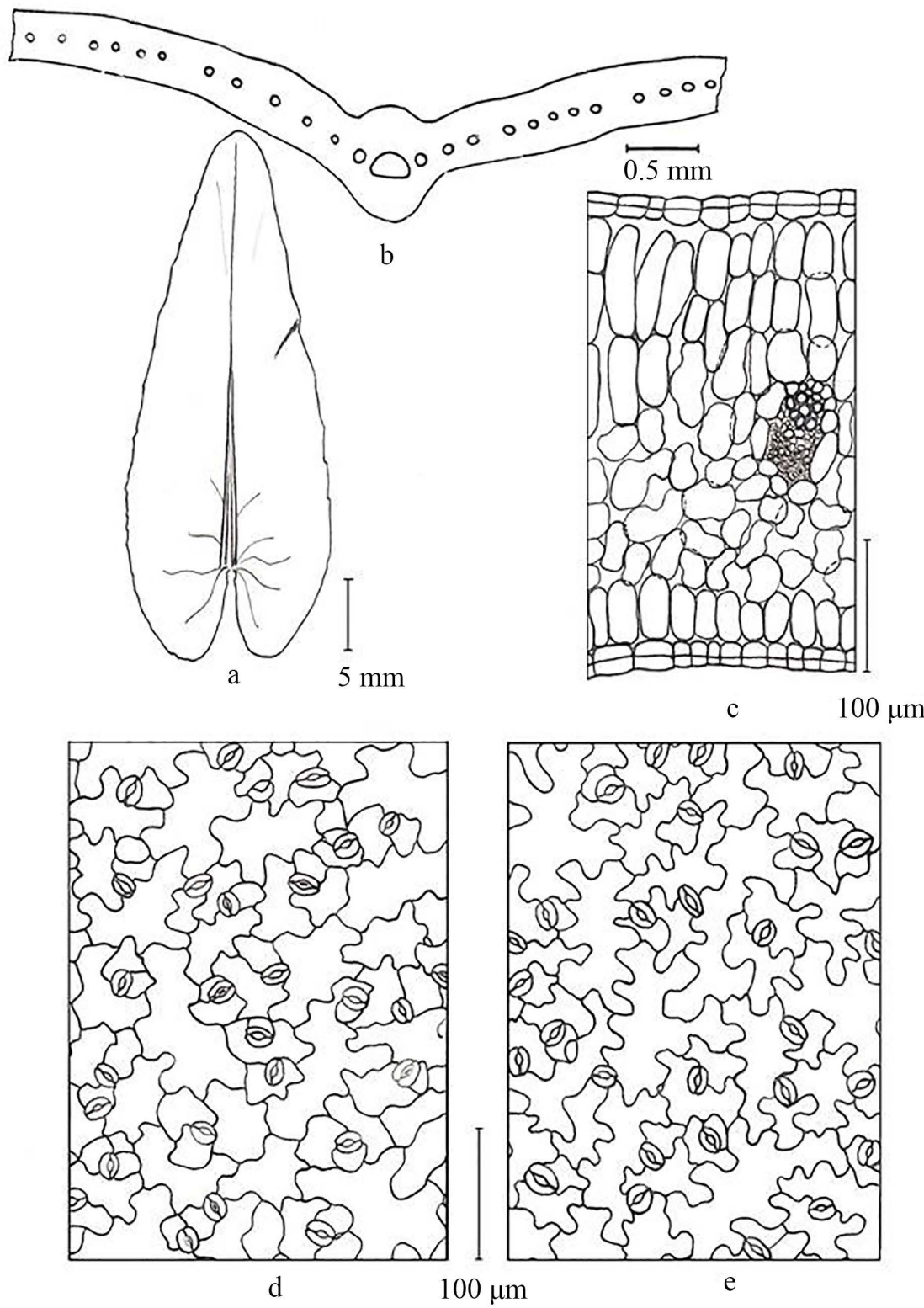

Figure 14. The structure of the middle sheet of Tauscheria lasiocarpa: a-appearance; b-cross-sectional diagram; c-detail of a mesophyll; d-adaxial epidermis; e-abaxial. Magnification- 0.5 - $5 \mathrm{~mm}, 100$ micron. 
(Diptychocarpus strictus), and only in Leptaleum filifolium is valky. It is pubescent with different types of trichomes: stellate, dendroid (species of Meniocus linifolius), equidibulus (Streptoloma desertorum), unequal (species of Strigosella, Leptaleum filifolium), unicellular hooked (Leptaleum filifolium). The density of pubescence is inversely correlated with the thickness of the outer wall of the epidermis. In densely pubescent species, the outer wall of the epidermis is thin. Epidermal cells are flattened with wavy or winding walls; almost straight cell walls of the adaxial epidermis in the species Strigosella, Tetracme. The stomata are randomly located, numerous, not submerged, mainly anomocytic, hemiparacitic, anisocytic. Isolate-palisade ( $80 \%$ of species) mesophyll prevails with a different ratio of palisade cells (1 - 3). 4 - 7-row spongy parenchyma with intercellular spaces, especially large in species Isatis, Lachnoloma, Strigosella. Vascular bundles of all kinds are sclerified. The main protective features of the leaf of species of the family Brassicaceae are pubescence and sclerification of vascular bundles. Other indicators: numerous not submerged stomata, large intercellular spaces, thin wall of epidermal cells are signs of mesomorphic. A.F. Ilyinskaya [22] considers the ephemers of the Brassicaceae family a reduction line of development, in contrast to the perennial advanced xeromorphic species. We consider the mesomorphic and xeromorphic lines of development ancient and independent.

\section{Conflicts of Interest}

The author declares no conflicts of interest regarding the publication of this paper.

\section{References}

[1] Tsvelev, N.N. (2011) On the Russian Names of Families of Angiosperms. News of the Systematics of Higher Plants: A Collection. M.-SPb, Moscow, 24-29.

[2] The Plant List (2013) Brassicaceae Version 1.1. http://www.theplantlist.org

[3] Nechaev, N.T., Vasilevskaya, V.K. and Antonova, K.G. (1973) Life Forms of the Karakum Desert. Science, Moscow, 244.

[4] Ubaidullaev, W.U. (1959) Formation of Isopalisade Leaves in the Genus Delphinium L. Uzbek Biological Journal, 1, 21-26.

[5] Ubaidullaev, W.U. (1959) Anatomical and Environmental Study of Ephemerals and Ephemeroids of the Foothills of the Western Tien Shan. Academy of Sciences of the Uzbek SSR, Tashkent, 15.

[6] Volkova, E.N. (1960) On the Anatomy of a Leaf of Desert Ephemera. Scientific Notes Moscow Society of Testers of Nature, 79, S569-580.

[7] Begbaev, G.F. (1995) The Structure of the Leaf Organs of Desert Ephemera of the Genus isatis L. Uzbek Biological Journal, 2, 47-50.

[8] Begbaev, G.F. (1997) Mesophyll Types of Ephemeral Leaf in Southwestern Kyzylkum. Tr. International Conference on the Anatomy and Morphology of Plants, Dyada, St. Petersburg, 225-226.

[9] Begbaev, G.F. (2002) Types of Mesophyll in the Ephemeral Leaf of Southwestern Kyzylkum. Tr. International Conference on the Anatomy and Morphology of Plants, 
BIN RAS, St. Petersburg, 259.

[10] Begbaev, G.F. (2002) Heterophyllia of Some Ephemera of This. Asteraceae. Results and Prospects for the Development of Botanical Science in Kazakhstan. Materials of the Scientific Conference, Almaty, Kazakhstan, 27-31.

[11] Tursynbaeva, G.S. and Butnik, A.A. (2015) Leaf Structure of Species of Sem. Asteraceae Biological and Structural-Functional Foundations of the Study and Conservation of Biodiversity in Uzbekistan. FAN, Tashkent, 308-314.

[12] Metcalfe, C.R. and Chalk, L. (1957) Anatomy of Dicotiledons. Oxford, 725-1500.

[13] Rao, N. and Inamdar, I. (1983) Leaf Architectural Studies in the Brassicaceae. The Botanical Magazine = Shokubutsu-gaku-zasshi, 96, 14-28. https://doi.org/10.1007/BF02489571

[14] Karimov, K.K., Cherker, R.I., Nikolaev, M.I., et al. (1965) On the Biochemical Characterization of Weida (Isatis boissieriana Reicheneb.). Plant Physiology-Agriculture, Dushanbe, 39-46.

[15] Momotov, I.F. (1962) Kyzylkum Desert Station. The Botanical Journal, 47, 1858-1862.

[16] Babushkin, L.N. (1971) Physical and Geographical Conditions of Uzbekistan. Climate. Vegetative Cover of Uzbekistan. FAN, Tashkent, 48-62.

[17] Lee, A.D. (1973) Rhythm of Development and Bioecological Productivity of the Main Communities of Southwestern Kyzylkum. Theoretical Foundations and Methods of Phytomelioration of Desert Pastures of Southwestern Kyzylkum. FAN, Tashkent, 36-59.

[18] An, P.A., Gringof, I.G. and Konovalov, N.S. (1978) Microclimatic Features of Some Landscapes of Southwestern Kyzylkum. Hydro Meteorological Center, Moscow, 64-94.

[19] Zakharevich, S.F. (1954) On the Methodology for Describing the Epidermis of the Leaf. West. LSU. Leningrad, 65-75.

[20] Barykina, R.P., Chubatova, N.V., et al. (2005) A Large Workshop on the Ecological Anatomy of Flowering Plants. Comrade Scientific KMK, Moscow, 77.

[21] Dospekhov, B.A. (1968) Fundamentals of Statistical Processing of Research Results. Kolos, Moscow, 336.

[22] Ilyinskaya, A.F. (1986) The System of the Genus alyssum L. (Cruciferae) and the Main Directions of Evolution. In: Modern Problems of Phylogeny, MOIP, Moscow, 83-84. 